\title{
Glossary of key concepts
}

A

Active agents: see human agency.

Active fathering: the 'hands on' involvement by fathers in the day-to-day care of their children.

Adaptation view: see classic demographic transition theory.

Agency: see human agency.

Agnatic systems: see patrilineal system.

Agrarian societies: societies that are characterized by sedentary agriculture that is productive enough to support classes of people who are not directly involved in subsistence production, such as political rulers, priests, soldiers and craftsmen.

Alliance: see rules of alliance.

Ambivalence/ambivalent relationship: intergenerational relationship in which roles and boundaries have to be constantly negotiated, resulting in mixed feelings and contradictory expectations.

Ascending familialism: intergenerational relationships characterized by the flow of resources from younger to older generations, for example from young adults towards their elderly parents.

B

Beanpole family structure: term to describe the increased relevance in contemporary families of vertical family relationships between, for example, great-grandparents, grandparents, parents and children. The emergence of the beanpole family is due to a combination of the following factors: the extension of life expectancy amongst contemporary grandparent generation, earlier marriage and childbirth amongst this grandparent generation than preceding and subsequent generations, and fewer births in the contemporary generation of children.

Birth cohort: a group of people born during a particular period or year. In this book four birth cohorts are presented: people born before 1935; between 
1945 and 1954; between 1965 and 1974; and those who were 9 years old when interviewed between 2007 and 2009.

Bourgeois family: the middle-class, nuclear family form which emerged in the course of modernization. In this family form private family property is passed on from a father to his descendent heir, usually a son and is also associated with an emphasis on domesticity.

Breadwinner family: family form whereby fathers attended to children's instrumental needs through their work outside the home and mothers attended to children's expressive needs through their work inside the home. See also expressive needs and instrumental needs.

Bricolage: in family studies bricolage is used to describe how, as people encounter new situations and challenges, their choices are guided by family memories, traditions and practices (see Duncan, 2011). In this way, family is always simultaneously a process of reproduction and innovation.

C

Civil partnership: legally recognized union of two people with rights similar, but not the same, as those of a married couple.

Clan: descent groups where the common ancestor has become mythical, and no direct genealogical link can be traced to living individuals. Lineages may be subsets of clans. See also lineage.

Classic demographic transition theory: theory that the trend towards smaller family sizes in wealthy, industrial societies was mainly due to economic modernization. See also demographic transition and innovation / diffusion view.

Cognatic descent system: see undifferentiated filiation / descent system.

Cohort: see birth cohort.

Common couple violence: in research on domestic violence the term denotes when both partners 'lash out' in the context of an argument.

Companionate / companionship family: where bonds between family members depended on the quality of inter-personal relationships - on feelings of affection and love. This family form became increasingly prevalent as a result of urbanization and industrialization. See also institutional family.

Completed fertility: the number of children actually born per woman in a cohort of women up to the end of their childbearing years.

Complex marriage systems: societal rules that specify whom the individual must not marry. See also elementary marriage systems.

Concerted cultivation: the ways in which middle-class parents invest time in extra-curricular, structured activities for their children in the company of adults, which contrast with working-class parents' approach in which children spend unstructured after-school time in the company of peers. By doing so, middle-class parents are said to provide their children with a better preparation for middle-class jobs. 
Conjugal family: also known as the 'nuclear family', the conjugal family unit consists of parents and their children.

Conservative welfare regime: in Gøsta Esping-Andersen's (1990) distinction amongst the 'three worlds' of welfare capitalism, the Conservative welfare regime intervenes in the market to preserve existing status inequalities such as those based on institutions like the family. See also social democratic welfare regime and liberal welfare regime.

Convergence thesis: key proposition of twentieth-century modernization theory, which stated that around the world social institutions, including the family, would tend to converge as societies underwent the modernizing processes of industrialization and urbanization. Goode (1963) argued that the diverse family patterns that existed around the world were being altered by modernization to converge on a conjugal family form. See also convergence to diversity.

Convergence to diversity: term coined by Boh (1989) to describe the common patterns of growing diversity in family forms in advanced industrial countries. See also convergence thesis.

Cultural ideals: standards that a society use to define the ways in which members should be treated and / or behave.

$\mathrm{D}$

Defamilialization: the degree to which individuals can uphold a socially acceptable standard of living, independently of family relationships, either through paid work or through the social security system (see Lister, 1994).

De-institutionalization of marriage: process whereby adult partnerships are no longer guided by a shared set of norms and expectations (see Cherlin, 2004).

Democratization (of family life): refers to increasing focus on the interests and well-being of individuals rather than the family as a corporate group. See also informalization of relationships.

Demographic transition: a shift from a demographic pattern of high fertility and high mortality, to one of low fertility and low mortality. See also classic demographic transition theory.

Demography: the scientific study of population. Demographers seek to explain shifts in the size and structure of human populations by examining trends in the number of births and deaths, and in patterns of ageing and migration.

Descending familialism: intergenerational relationships in which resources flow from older to younger generations. See also ascending familialism.

Displaying family: the concept of display refers to the ways in which family practices are embedded in wider systems of meaning: it refers to how people 'convey to each other and to relevant audiences that certain of their actions do constitute doing family things and thereby confirm that these relationships are family relationships' (Finch, 2007: 67). See also doing family.

Divorce rate: divorces per thousand married persons in a population. 
Doing family: how families are enacted in everyday practices oriented towards others who are identified as family members. 'In this way ... family practices are reflective practices; in being enacted they simultaneously construct, reproduce family boundaries, family relationships and possibly more discursive notions of the family in general' (Morgan, 2011: 163). See also displaying family.

Doing gender: the idea that gender is constructed in everyday, human interactions. Feminine and masculine traits are therefore the product of social interaction. See also doing family.

Domestication of childhood: the development of dedicated spaces and activities for children within controlled environments, for example playtime that is supervised by and / or structured by adults.

Domestic group: see household.

Dual-earner economy: contemporary family form that arose in the mid- to late twentieth century when women who had once worked inside the family home moved into the cash economy and took paid jobs alongside their male partners. See also family economy and family-consumer economy.

Dual-systems theory: also known as socialist feminism, Hartmann's (1979) dual-systems theory argues that women are marginalized by their dual role in modern society as both paid employee and mother. Women are exploited both in the workforce and in the home as they are more likely to secure lower paid employment than men, and more likely to deliver 'unpaid services' in the form of housework within the home. See also Marxist-Feminism, liberal feminism, radical feminism, structural-functionalism.

$\mathrm{E}$

Early adulthood: see formal adulthood.

Ecological fallacy: the logical error of making inferences about individuals based on observations about groups. See also individualistic fallacy.

Egalitarian individualism: social policy paradigm where the welfare and rights of the individual are not dependent on family status or role (see Fahey, 1998). See also patriarchal familism.

Elementary marriage systems: societal rules that specify the groups from which an individual must choose their spouse, thus ensuring different descent groups are socially linked through marriage. See also complex marriage systems.

Endogamy: marriage rules that prescribe the group from which a spouse must be taken. See also exogamy.

Enmeshed intergenerational lives: situation where young adults remain committed to caring for older family members, even as they recognize that this will affect their own life chances.

Ethnography: systematic study of a social group usually involving both observing and living amongst the group. Participant observation is a key technique of ethnography. 
European marriage pattern: historic pattern of family formation in which couples married and commenced childbearing relatively late. During the period between reaching adulthood and marriage many young adults spent a period of time in service to allow them to accumulate savings that would help them establish their own home.

Exogamy: marriage rules that ensure individuals marry outside their own kinship group. See also endogamy.

Expressive needs: children's need for daily nurturance, love and care in order to grow up well, as provided by parents. See also instrumental needs.

F

Family adaptive practices: theory that families adapt their household strategies in response to external constraints such as changing institutions, economic circumstances and political contexts.

Family configuration: a way of studying family relationships that focuses on networks of personal ties or personal communities.

Family-consumer economy: from the end of the nineteenth century through the middle of the twentieth century men's wages began to rise, and growing numbers of women began to take on the specialized role of homemaker. In such families women contributed to the household economy not by earning an income, but by managing the household income to ensure the well-being of all its members. See also family economy and dualearner economy.

Family economy: in agrarian societies all members of the household, both family members and servants, worked together to ensure the survival of the household as a unit of production and consumption. In such households there was no meaningful distinction between productive and reproductive labour. Work was differentiated by gender and age, and women's tasks tended to be consistent with caring for young children. Nevertheless, the importance of women's work for the survival of the family and household was recognized. See also family wage economy and family-consumer economy.

Family failure: a term sometimes used to refer to a failure to continue the family line through succession in agrarian society.

Family life cycle: the idea that family households move through a predictable sequence of stages from marriage to succession and family dispersal.

Family systems: family systems can be defined as preferred patterns of recruitment into households. They specify 'who should live with whom at which stages of the life course; the social, sexual, and economic rights and obligations of individuals occupying different kin positions in relation to each other; and the division of labour among kin related individuals' (Mason, 2001: 161). See also stem-family system.

Family wage economy: during the first phase of industrialization (from around the end of the eighteenth century through most of the nineteenth century), 
all household members pooled their labour to ensure their survival in the family wage economy. As much as they possibly could, men, women and children contributed wages to the household pot, for the benefit of the family as a whole. See also family economy and family-consumer economy.

Fertility rate: number of births per woman. See also total fertility rate and mortality rate.

Fertility transition: see demographic transition.

Fictive kin: people that treat one another as though they are related, despite having no biological or marital links.

Filiation: system whereby those considered an ancestor or a descendent of an individual are defined.

Formal adulthood: the transition of an individual to the status of adult. Hannan and Ó Riain (1993) described adulthood as 'comprised of a set of statuses which provide a basis for individual independence and for full civic status'. Until comparatively recently formal adulthood was associated with marriage and independent family formation. See also timing and sequencing of life transitions and unbundling of family life transitions.

G

Gatekeeping / maternal gatekeeping: term used in the study of the gender division of household labour to describe practices of mothers who are reluctant to relinquish responsibility over family matters.

Gender contract: power relationships between female and male members of a society that determine roles, responsibilities, privileges, status, sexuality and behaviour of men and women within households, communities, the market and the state.

Gendered moral rationalities: moral rationalities based on perceptions about gender roles, for example, ideas about what makes a 'good mother' and what makes a 'good father'. See also moral rationalities.

Gender stereotyping: generalizations about the characteristics of men and women. For example, the idea that women are the 'natural' parent and therefore fathers are not as good at caring for their children as mothers.

Gender symmetry: in research on domestic violence, the argument that women and men experience and perpetrate violence at similar rates.

Grand theory: 'A term coined by C. Wright Mills in The Sociological Imagination (1959) to refer to the form of highly abstracted theorizing in which the formal organization and arrangement of concepts takes priority over understanding the social world' (Scott and Marshall, 2009: 295).

$\mathrm{H}$

Historical period: an amount of time defined chronologically.

Homogamy: the tendency to choose marital partners from within our own social class or ethnic group. 
Horticultural societies: a society that generally combines gathering food from the wild with agriculture, using simple tools and long fallowing periods.

Household: the set of people who share a living space and pool their resources.

Household economy / household economics: practices of production and consumption that are organised within households. The theoretical approach is particularly associated with the work of Gary Becker. Family behaviour is explained with reference to the idea that members act rationally to maximise the well-being of their household.

Human agency: the extent to which people are planful, make choices and take action with reference to their understandings of their own potentialities and futures.

I

Ideal type: in Weberian theory ideal type aims to describe the essential characteristics of an institution. In family studies ideal type is an abstract statement of what were thought to be the essential features of the family as an institution. See also cultural ideals.

Incest: sexual relationship between two closely related 'blood' relatives. In every society incest is prohibited, but the definition of incestuous relationships varies to some extent across societies.

Independent household: the establishment of a family and residence of one's own that is separate to the home of the family of origin. See also formal adulthood.

Individualism: an ideology or stance which emphasises the needs of the individual. Individualism is sometimes contrasted with collectivism, where the needs of the group as a collective take precedence over the needs of each individual member. See also individualization.

Individualistic fallacy: the logical error of making inferences about the group based on observations about individual cases. See also ecological fallacy.

Individualization: societal process whereby values and institutions increasingly centre on requirements of individuals rather than as collectives. See also individualism.

Individualized marriage: marriage in which relationships are evaluated according to how well they meet each partner's sense of self and the expression of their feelings.

Inductive approach: in social research, an inductive approach commences with observation of a social phenomenon and from these observations generalizations are drawn out which are then used to build social theory.

Informalization of relationships: in family studies, this term describes the transformation of relationships between family members whereby more traditional, authoritarian models of parenting have started to give way to more democratic ones. See also democratization (of family life).

Innovation / diffusion view: theory that modernization affected family sizes 
primarily through the diffusion of new values emphasizing individualism and self-fulfilment. See also classic demographic transition theory.

Institution: in sociology the term institution refers to a system of behavioural and relationship patterns that function across an entire society, which order and structure the behaviour of individuals by rules, norms or patterns of behaviour. Social institutions like the family have been thought of as comprising a set of interdependent roles governed by socially agreed rules of behaviour (see Cherlin, 2004). See also role.

Institutional family: proposed by Ernest Burgess (1948), where the bonds between family members are enforced by law, custom, public opinion and duty. See also companionate relationship family.

Instrumental needs: children's need for material conditions for survival, as provided by parents. For example food, clothing, housing and so on. See also expressive needs.

Intergenerational flow: refers to the movement of help and assistance between generations. See also intergenerational transfers and intergenerational relationships.

Intergenerational relationships: relationships between older and younger generation in families and societies. See also intergenerational flow and intergenerational transfers.

Intergenerational solidarity: the ways in which people of different generations in a society live together, help each other and depend on one another in their daily lives.

Intimate terrorism: in research on domestic violence, the term denotes where one partner uses violence as a tactic within an overall pattern of control of the other.

Intergenerational transfers: financial assistance or benefits in kind given from one generation to another. See also intergenerational flow and intergenerational relationships.

J

Judicial separation: according to Courts Service Ireland (www.courts.ie), 'When a couple cannot agree the terms by which they will live separately, either party can apply to the court for a decree of judicial separation [...] The main difference in law between divorce and judicial separation is that a divorce allows both parties to remarry whereas a judicial separation does not'.

K

Kin: the group of living persons who are related to us.

Kindred: the group of relatives we recognize through the genealogical links in our memory.

Kinship: a social institution that governs a society to a greater or lesser extent. In some societies, the institution of kinship governs all aspects of social life, including politics, the economy and religion. The kinship group 
to which an individual belongs may determine who they marry, and where they work and live.

$\mathrm{L}$

Late modernity: a term used to signify a body of work that rejects the idea that society has transitioned to a new era of post-modernism. Proponents of late modernity tend to argue instead that in contemporary society there has been an intensification of some aspects of modernity. See also post-modernism.

Liberal feminism: liberal feminist theorists challenged structuralfunctionalist theories by arguing that gender roles within families were not given in nature; rather they were perpetuated through a process of socialization and can therefore be altered through tools such as education and anti-discriminatory legislation. They also emphasized the extent to which gender roles were not just different, they were unequal: the unpaid work of meeting the expressive needs of families within the home was of lower status within society - that is, less highly valued - than working for pay to meet the family's instrumental needs. See also dual-systems theory, Marxist-Feminism, radical feminism and structural-functionalism.

Liberal individualism: a political philosophy 'that stresses the importance of the individual and the value attached to individual freedom and individual choice. The philosophy is frequently contrasted with collectivism, where the collective rather than individual good is paramount' (Scott and Marshall, 2009: 342).

Liberal welfare regime: in Gøsta Esping-Andersen's (1990) distinction amongst the 'three worlds' of welfare capitalism, the Liberal welfare regime is oriented primarily towards supporting the market. Social welfare transfers in this regime are targeted towards marginalized and stigmatized groups. See also social democratic welfare regime and conservative welfare regime.

Life-chances: the opportunities each individual has to improve his or her quality of life.

Life-course: term denoting how an individual's life evolves over time, in a linear sequence of significant events through a series of socially defined transformations.

Life-course perspective: an examination of how a person's life evolves over time, within structural, social and cultural contexts. This method allows us to consider how key events in the life of an individual influence the decisions that they make, which thus direct the course which their life takes.

Life stage: term used to describe a period of time in a person's life, for example grandparenthood, middle age, adolescence, parenthood, childhood and old age.

Life transition: a period of significant change in an individual's life, such as setting up a first home with a spouse, or starting a family. 
Lineage: a group of individuals who share a common ancestor. Lineages are at the heart of how unilineal descent systems are organized. See also unilineal filiation.

Linked lives: the principle of linked lives emphasizes how individual lives are embedded in sets of social relationships - especially those of family and kin - that travel with us through the life course.

Longevity revolution: since the 1950s, most of the change in life expectancy in European societies can be attributed to the extension of life in old age. See also secular shift in ageing.

Longitudinal data / longitudinal study: research that is conducted over a long period of time, usually many years. Data about key characteristics are repeatedly collected at specified intervals over this time period. See also panel study and prospective data / prospective study.

M

Macro-societal changes: large-scale social processes, patterns and trends of whole societies. See also micro-practices.

Male-breadwinner model: see breadwinner family.

Marital breakdown: deterioration of marital relationships leading to separation or divorce.

Marxist-Feminism: both Marxist and dual-systems theorists sought to understand families as sites where the processes giving rise to class and gender inequality intersected. They argued that the unpaid work carried out by women within the home acted as a kind of subsidy to capitalist employers and the state, making it possible to maximize profits by keeping down wages while also perpetuating inequalities between women and men. See also dual-systems theory, liberal feminism, radical feminism and structural-functionalism.

Matchmaking: practice of arranged marriage that was common in the stemfamily system in Ireland, in which an inheriting son was 'matched' with a suitable bride.

Matriarchy / matriarchal family: society in which the mother or oldest female heads the family. Descent and relationship are determined through the female line. See also patriarchy / patriarchal family and matrilineal system.

Matrilatral ancestors: ancestry that is traced through the female line. See also lineage and patrilateral ancestors.

Matrilineal system: system whereby names, privileges, rights and obligations are passed from mother to daughter. See also matriarchy / matriarchal family, patrilineal system and unilineal descent system.

Matrilocal residence: where a married couple lives with, or near, the wife's family. This typically occurs in matrilineal societies. See also matrilineal system and patrilocal residence.

Micro-practices: small-scale interactions between people. See also macrosocietal changes. 
Modernization / modernization theory: in the decades after the Second World War, sociologists developed modernization theory to explain the rise of wealthy, industrial societies and to contrast them with poorer societies both in the present and the past - that were thought to be more 'traditional'. Modernization was described as a set of fundamental, interdependent changes in the economy, the political system, social institutions and social values. See also post-modernism.

Modes of production: the Marxist concept of modes of production refers to the major ways in which societies are organized in order to meet the material needs of their members, for food, warmth and shelter, and to ensure their continuity over time.

Monogamy / monogamous relationship: a form of relationship in which an individual has only one partner during their lifetime, or at any one time.

Moral rationalities: term to describe how the actions of people are primarily guided by social and relational understandings rather than economic and rational choices. While economic considerations are important they are secondary to moral considerations. For example if a parent follows a gendered moral rationality, the decisions they make about their role in the family may be centred on what it means to be a good mother or father.

Mortality rate: number of deaths per population. See also fertility rate.

N

Nostalgic construction of childhood: Christopher Jenks (1996) described the nostalgic construction of childhood in late modernity as a prevailing belief that past childhoods were better than those of today.

Nuclear family: see conjugal family.

$\mathrm{O}$

Orderly transition to family formation: term to describe a transition to independent household formation that is consistent with social norms and institutional constraints around the timing and sequencing of life transitions during a particular period. See also timing and sequencing of life transitions.

$\mathrm{P}$

Panel study: used in longitudinal research, a group of research participants are followed over time and interviewed at specified intervals often over many years. A key feature of this research design is that repeated measures are collected from the same group of people at different points in time. See also prospective data / prospective study.

Patriarchal familism: social policy paradigm where the welfare of the individual is dependent on their inclusion in a cohesive family unit, and their legal status is defined by reference to family status. See also egalitarian individualism. 
Patriarchy / patriarchal family: in this family structure the father is the head of household, and all titles and inheritance are traced through the father's line. See also patrilocal residence, matriarchy / matriarchal family.

Patrilateral ancestors: also known as 'agnatic', ancestry that is traced through the male line. See also lineage and matrilatral ancestors.

Patrilineal system: also known as 'agnatic', system where names, privileges, rights and obligations are passed from father to son. See also matrilineal system, patriarchy / patriarchal family and unilineal descent system.

Patrilocal residence: where a married couple lives with, or near, the husband's family. This typically occurs in patrilineal societies. See also matriarchy / matriarchal family, patriarchy / patriarchal family and patrilineal system.

Period total fertility rate: see total fertility rate.

Personal communities: a group that are tied together by relationships that are kin-like in terms of the meanings and commitments associated with them, despite the absence of actual kin relationships between members. The individual's personal community is usually chosen on the basis of egalitarianism and the quality of relationship provided by the members.

Polygamy: an individual being married to two or more people.

Post-modernism: aesthetic movement that originated in the arts during the early twentieth century in reaction to modernism. The post-modern movement emphasised a plurality of fragmentary forms while rejecting any claim to representational realism. In literature and social theory the movement is associated with post-structuralism. See also post-modernist theory and late modernity.

Post-modernist theory: in sociology of the family, Stacey (1990) argued that the post-modern family was not a single functional type, but rather a diversity and fluidity of forms as people moved in and out of different family settings, developing complex kin networks over the course of their lives. See also post-modernism.

Practices: actions and decisions that are governed to some extent by 'taken for granted' understandings or habit.

Primary research data: original data that is collected by a researcher, for example by conducting research 'in the field' such as interviewing or surveying people. See also qualitative data.

Primogeniture: an inheritance practice common in rural Ireland in the twentieth century where the eldest or first born son inherited the entire family estate upon his father's retirement. See also stem-family system.

Prospective data / prospective study: a prospective study is a cohort study that follows a group of research participants over time. Research participants may differ with respect to certain characteristics, and the 
longitudinal data produced by this study is used to determine how these characteristics affect rates of a certain outcomes. See also longitudinal data / longitudinal study, panel study and retrospective data / retrospective study.

Pseudonym: the name given to an individual, which differs from his or her original or true name, to conceal the identity of that individual. A pseudonym can be given as a first name, or as both a first and surname.

Pyramid family structure: a term to describe a demographic profile where high rates of fertility give rise to larger families and long, overlapping generations. See also beanpole family structure.

Q

Qualitative approach: methodological approach to the collection and analysis of qualitative data. See also qualitative data.

Qualitative data: richly descriptive, non-numerical data that are usually collected through interview methods, observational methods or the thematic analysis of texts.

$\mathrm{R}$

Radical feminism: radical feminist theorists developed an analogy between gender and social class, arguing that families were organized around the domination and exploitation of women's sexuality and reproductive capacities. See also dual-systems theory, liberal feminism, MarxistFeminism and structural-functionalism.

Rational decision-making: usually refers to decision-making oriented towards maximizing economic or material well-being.

Relationships of choice: family-type relationships based on personal preferences rather than societal rules or conventions often used to describe family relationships of LGBT (see Weeks et al. 2001). See also fictive kin.

Resilience: the capacity to bounce back in the face of adverse circumstances.

Retrospective data / retrospective study: a retrospective study generally involves the research interviewee recounting events that have already taken place, for example retrospective data is collected during a life story interview. See also prospective data / prospective study.

Rules of alliance: societal rules which delineate the persons whom an individual is permitted to marry.

Role: the behaviour or expectations attached to the individual's social position.

S

Sandwich generation: term to describe a generation of adults in the early twenty-first century that are likely to experience greater pressures as a result of having to care for children and elderly parents at the same time, due to a combination of greater longevity in old age and the tendency for younger adults to postpone parenthood. 
Secular shift in ageing: Peter Laslett (1987) termed the reduction in the risk of dying at all ages alongside reduced fertility that took place in most European societies between 1950 and 1960 as a secular shift in ageing. The transition occurred, according to Laslett, when two conditions were met: (1) a quarter of all adults had passed the age of 60; (2) at least half of all males surviving to age twenty-five can expect to live to age seventy. See also longevity revolution.

Selection bias: in social research if observations are selected so that they are not independent of outcome variables they may be affected by selection bias and this can result in biased and inaccurate inferences in the findings.

Social capital: refers to the idea that nature and quality of relationships between people can act as a resource for improving quality of life.

Social democratic welfare regime: in Gøsta Esping-Andersen's (1990) distinction amongst the 'three worlds' of welfare capitalism, the social democratic welfare regime is oriented towards de-emphasizing the market and reducing the inequalities arising under capitalism. See also conservative welfare regime and liberal welfare regime.

Social institution: see institution.

Socialization: process by which human's learn, starting from infancy, how to function in social life. Socialization is a central influence on the individual's behaviour, beliefs and actions.

Statistically representative: an unbiased indication of what entire population is like based on inferences about a sample from that population.

Stem-family system: a family system in which only one heir can marry in the family household. Sometimes this household involves three generations living together following the retirement of the older couple. In rural Ireland typically the couple's firstborn son remained in his parents' household after his marriage, and his spouse moved into the home of her in-laws. The younger couple then raised their own children in the family home alongside their grandparents. Other sons and daughters had to leave the parental household in order to start families of their own. However, sometimes unmarried brothers and sisters remained in the family home as unwaged labourers. See also family systems.

Structural-functionalism: classical sociological theory that saw society as a complex system whose parts work together to promote solidarity. Scholars within the tradition of structural-functionalism believed that the best way of explaining a particular social institution, such as the family, was to show what function or requirement it met for the preservation of society as a whole. See also dual-systems theory, liberal feminism, MarxistFeminist theory, radical feminism.

$\mathrm{T}$

Third Age: during the twentieth century a new phase emerged between adult independence and decrepitude - a comparatively healthy 'Third Age' with 
fewer immediate responsibilities and with opportunities for new forms of individual achievement and fulfilment. This new phase was made possible in part by the extension of life but also by the institutionalization of retirement through the introduction of old-age pensions (see Laslett 1987). See also secular shift in ageing.

Timing and sequencing of family life transitions: phrase to describe the stages by which an individual leaves the home of their family of origin to establish their own independent household, enters employment thereby gaining financial independence from their family of origin, marries and / or starts a family of their own. See also formal adulthood and orderly transition to family formation.

Total fertility rate (TFR): an estimate of annual rates of fertility. It is calculated as the average number of births a woman would have by the end of her reproductive years, if fertility levels at each age during her childbearing period remained constant at the levels prevailing at a given time.

Transformation of gender roles: refers to the significant change in customary roles for men and women that occurred from the 1970 s onwards in most western societies.

Transnational familial networks: relationships amongst extended family members who are living in different countries due to migration.

U

Unbundling of family life transitions: whereas in the 1950s and 1960, young adults left home, entered employment, married and started a family in a tightly ordered sequence of events within a comparatively short period of time, today these transitions have become separated and prolonged, and their sequencing has become more variable. See also formal adulthood and timing and sequencing of life transitions.

Undifferentiated filiation / descent system: family system where ancestors from both the father's and the mother's lineage are recognized as part of the kinship group. See also unilineal filiation / descent system.

Unilineal filiation / descent system: family system where only ancestors and descendants from either the father's or mother's side are recognized as part of the kinship group. See also matrilineal system, patrilineal system and undifferentiated filiation / descent system.

Unstable family: according to Le Play in an unstable family the sons would leave their parents' households to marry and set up on their own 'as soon as they gain any confidence in themselves' (Le Play, 1872: 41). While this system favoured innovation, it failed to ensure the transmission of custom, values and practices from one generation to another, and could lead to the isolation and abandonment of people in old age (Mogey, 1955: 313). 
V

Values: socially based, shared ideas about the proper or right way to live.

W

Welfare-state: term used to describe the state provision of services and supports that are funded by the state exchequer to ensure a basic standard of living for its citizens. Examples of services and supports include subsidised health care, unemployment support payments and subsidised education. See also conservative welfare regime, liberal welfare regime and social democratic welfare regime. 